\title{
Jejunal permeability to water and electrolytes in patients with chronic intrahepatic hypertension: evidence for a role of aldosterone
}

\author{
B Duclos, P Bories, J C Mathieu-Daude, H Michel
}

\begin{abstract}
Acute prehepatic portal hypertension induces intestinal secretion in animal models. In the course of chronic liver disease, however, these changes are not observed, despite higher portal pressures than those found in experimental studies. Eight patients without diarrhoea and with chronic alcoholic liver disease were examined for evidence of increased jejunal secretion; their suprahepatic wedge pressure was raised from 21 to $45 \mathrm{mmHg}$ (mean $34.6 \mathrm{mmHg}$ ). Jejunal perfusion with a triple lumen catheter and a proximal occluding balloon was used to study net flows of water and chloride as well as net and unidirectional flows of sodium and potassium. No statistical difference in intestinal flows of water and electrolytes was noted between cirrhotic patients and control subjects after infusion with a $30 \mathrm{mmol} / \mathrm{l}$ glucose solution. Infusion with a $30 \mathrm{mmol} / \mathrm{l}$ mannitol solution resulted in a lower absorption of water, $\mathrm{Na}, \mathrm{K}$, and $\mathrm{Cl}$ than with the glucose solution. A higher rate of $\mathrm{Na}$ secretion was observed in cirrhotic patients than control subjects after infusion with $30 \mathrm{mmol} / \mathrm{l}$ mannitol $(\mathbf{p}<0.01)$. In addition, the rate of $\mathrm{Na}$ secretion was higher in cirrhotic patients than in control subjects $(p<0.05)$. There was no correlation between the net flow of $\mathrm{Na}$ and the suprahepatic wedge pressure. $\mathrm{A}$ second perfusion with a $30 \mathrm{mmol} / \mathrm{l}$ glucose solution was given 75 minutes after a bolus injection of spironolactone (400 mg). Net flows of $\mathrm{Na}$ and $\mathrm{Cl}$ were lower in cirrhotic patients than in control subjects $(p<0.05)$ because of a lower absorption of $\mathrm{Na}$. Patients with gradually developing portal hypertension have moderate jejunal secretions of $\mathrm{H}_{2} \mathrm{O}$ and electrolytes which we assume are partly masked by increased absorption resulting from hyperaldosteronism. In contrast to animal models, this mechanism may be part of the jejunal adaptation to permeability in acute portal hypertension.
\end{abstract}

Departments of Gastroenterology and Nuclear Medicine, Hôpital Saint-Eloi, Montpellier, France B Duclos P Bories

J C Mathieu-Daude H Michel

Correspondence to: Dr B Duclos, Service d'Hepato-Gastroenterologie, Hôpital de Hautepierre, 67098 Strasbourg Cedex, France.

Accepted for publication 20 August 1990
The effects of chronic portal hypertension on the human gastric mucosa are beginning to be clearly described. ${ }^{12}$ There have been few studies, however, on the effects of chronic intrahepatic portal hypertension of the mucosa of the small intestine from the point of view of morphology ${ }^{3}$ or hydroionic transfer. ${ }^{45}$ Animal studies were carried out using an acute prehepatic portal hypertension induced by stricture of the portal vein. This model is very different from the portal hypertension caused by cirrhosis. Under these conditions, the permeability of the small intestinal mucosa was shown to be increased, and intestinal secretion of water and electrolytes occurred when a pressure of $20 \mathrm{mmHg}$ was obtained in the portal vein. $^{6-11}$ Furthermore, this secretion gradually increased in proportion to the portal pressure value for pressures greater than $23 \mathrm{mmHg}$. "In man, diarrhoea is not uncommon after acute portal thrombosis but it is of short duration. In patients with chronic liver disease, intrahepatic portal hypertension gradually develops. Portal pressure frequently exceeds $23 \mathrm{mmHg}$ and they seldom suffer watery diarrhoea because of intestinal secretion. In cirrhotic patients, neither Talley et $a l^{5}$ nor Norman $e t ~ a l^{4}$ showed increased intestinal secretion related to portal hypertension. In the latter study the authors point out that aldosterone would have an effect upon the small intestine because its blood concentration was negatively correlated with the degree of dilatation of the intestinal intercellular spaces.

The aim of this study was to determine whether water or electrolytic secretions, or both, would occur in the jejunum of patients with chronic intrahepatic portal hypertension caused by alcoholic cirrhosis (the patients being deprived of alcohol). In order to investigate a specific effect of aldosterone, we used spironolactone, a competitive blocker of aldosterone that acts upon the kidney and both large and small intestine. ${ }^{12}$

\section{Patients and methods}

Patients were divided into two groups. Group I comprised eight alcoholic patients with cirrhosis (five men, three women) with a mean age of 57 years (range 50-68 years). All patients were in hospital and were deprived of any alcoholic drink for at least two weeks. All had extensive, noninaugural ascites and all belonged to group $\mathrm{C}$ of the Child and Pugh classification. No diuretic was given for at least one week before the beginning of the study and restriction of water $(<1$ litre/day) and $\mathrm{Na}(<1 \mathrm{~g} /$ day $)$ was the only treatment.

Group II comprised six patients with a mean age of 45 years (range 30-54 years), who were in hospital for irritable bowel syndrome. None had diarrhoea, small intestine disease detected by a malabsorption test, oesophageal or gastric varices visible by endoscopy, or any clinical or laboratory signs of acute or chronic liver disease.

METHODS

Measurement of portal pressure

Measurement of portal pressure was carried out 
only in the eight cirrhotic patients by catheterisation of the suprahepatic veins using a Teflon 9FG radiopaque catheter. The inferior vena cava, free suprahepatic, and suprahepatic wedge pressures were measured using a recording of the withdrawal curves. The suprahepatic wedge pressure was considered to be the equivalent of the portal pressure.

\section{Intestinal perfusion}

The small intestine was perfused with a nonabsorbable marker polythylene glycol $\mathbf{4 0 0 0}$ $\left(\right.$ PEG 4000) ${ }^{13}$ using a triple bore catheter with a proximal balloon. ${ }^{14}$ is The catheter was introduced at least 12 hours before the perfusion and its passage along the intestinal tract was ensured by a mercury weight. Progression of the catheter was stopped when the point of perfusion, identified by fluoroscopy, reached the angle of Treitz. All patients were resting and fasting for at least 12 hours before the beginning of the perfusions. The segment of intestine studied was the proximal jejunum. The proximal portion of intestine was excluded by inflating the balloon with 30 to $50 \mathrm{ml}$ of air. This occlusive effect was confirmed by injection of sulphobromophthalein proximal to the balloon. The perfused solutions were kept at $37^{\circ} \mathrm{C}$ and propelled by a peristaltic pump (Technicon Instruments Company Ltd, London) with a flow rate of $10 \mathrm{ml} /$ minute (standardisation was verified before and after perfusion). Two types of solutions (SI and SII) were infused in succession. Their order was selected at random and there was an interval of 30 minutes between the two. The two solutions had a common base composition: PEG 4000, $10 \mathrm{~g} / \mathrm{l} ; \mathrm{NaCl}, 130 \mathrm{mmol} / \mathrm{l}$; and $\mathrm{KCl}, 5 \mathrm{mmol} / 1$. In addition, the solutions contained $4 \mu \mathrm{Ci} / 1$ of $\mathrm{Na}^{22}$ and $15 \mu \mathrm{Ci} / 1$ of $\mathrm{K}^{42}$ in order to measure unidirectional flux of $\mathrm{Na}$ and $\mathrm{K}$. SI contained $30 \mathrm{mmol} / \mathrm{l}$ of glucose to stimulate absorption of water and electrolytes. SII contained $30 \mathrm{mmol} / \mathrm{l}$ of mannitol to maintain an osmolarity equal to that of SI,

TABLE I Clinical data of the eight patients with alcoholic cirrhosis

\begin{tabular}{llllllll}
\hline $\begin{array}{l}\text { Patient } \\
\text { no }\end{array}$ & $\begin{array}{l}\text { Age } \\
\text { (years) }\end{array}$ & Sex & faundice & Encephalopathy & Ascites & $\begin{array}{l}\text { Oesophageal } \\
\text { varices }\end{array}$ & $\begin{array}{l}\text { Stool weight } \\
(\mathrm{g} / 24 \mathrm{~h})\end{array}$ \\
\hline $\mathbf{1}$ & $\mathbf{6 8}$ & $\mathrm{M}$ & + & 0 & + & + & 70 \\
2 & 60 & F & + & + & + & + & 120 \\
3 & 58 & F & 0 & 0 & + & + & 195 \\
4 & 57 & M & 0 & + & + & + & 170 \\
5 & 55 & M & 0 & + & + & + & 210 \\
6 & 50 & M & 0 & + & + & + & 95 \\
7 & 50 & F & + & + & + & + & 160 \\
8 & 58 & M & 0 & + & + & + & 220 \\
\hline
\end{tabular}

TABLE II Haemodynamic and biological data from the eight cirrhotic patients

\begin{tabular}{|c|c|c|c|c|c|c|c|}
\hline $\begin{array}{l}\text { Patient } \\
\text { no }\end{array}$ & $\begin{array}{l}\text { Suprahepatic } \\
\text { wedge pressure } \\
\text { (mmHg) }\end{array}$ & $\begin{array}{l}\text { Porto-caval } \\
\text { gradient } \\
(\mathbf{m m H g})\end{array}$ & $\begin{array}{l}\text { Total } \\
\text { protein } \\
(\mathrm{g} / \mathrm{l})\end{array}$ & $\begin{array}{l}\text { Albumin } \\
(\mathrm{g} / \mathrm{l})\end{array}$ & $\begin{array}{l}\text { Prothrombin } \\
\text { time }(\%)\end{array}$ & $\begin{array}{l}\text { Aldosterone } e^{\star} \\
(\mathrm{ng} / 100 \mathrm{ml})\end{array}$ & $\begin{array}{l}\operatorname{Renin} \star \\
(n g / m l / h)\end{array}$ \\
\hline $\begin{array}{l}1 \\
2 \\
3 \\
4 \\
5 \\
6 \\
7 \\
8 \\
\text { Normal }\end{array}$ & $\begin{array}{l}21 \\
45 \\
42 \\
40 \\
26 \\
31 \\
40 \\
32\end{array}$ & $\begin{array}{l}17 \\
36 \\
32 \\
31 \\
21 \\
28 \\
28 \\
31 \\
<8\end{array}$ & $\begin{array}{l}73 \\
58 \\
74 \\
78 \\
64 \\
72 \\
73 \\
69 \\
60-80\end{array}$ & $\begin{array}{l}38 \\
30 \\
27 \\
30 \\
29 \\
26 \\
30 \\
28 \\
35-55\end{array}$ & $\begin{array}{l}65 \\
22 \\
50 \\
45 \\
65 \\
45 \\
50 \\
33 \\
>70\end{array}$ & $\begin{array}{l}25 \\
73 \\
76 \\
71 \cdot 2 \\
47 \cdot 2 \\
32 \\
54 \\
17 \cdot 6 \\
6-15\end{array}$ & $\begin{array}{l}5 \cdot 1 \\
\text { ND } \\
51 \cdot 8 \\
\text { ND } \\
14 \cdot 7 \\
9 \cdot 8 \\
16 \cdot 7 \\
2 \cdot 3 \\
<5\end{array}$ \\
\hline
\end{tabular}

^Expressed as the means of the values measured on three consecutive days. without stimulating $\mathrm{H}_{2} \mathrm{O}$ and electrolyte absorption. The third stage of the study involved a further perfusion with SI, waiting 75 minutes after an intravenous injection of $400 \mathrm{mg}$ spironolactone. Samples were collected under the following conditions: there was a minimum equilibration time of 30 minutes before collection of samples ( $25 \mathrm{~cm}$ distal to the point of perfusion) by gentle aspiration with a syringe; each sample was collected over 10 minutes; four samples were collected for each solution perfused; and the absence of blood and sulphobromophthalein was confirmed by means of a colorimetric method.

\section{Terminology}

Movement out of the bowel into the body is referred to as insorption, movement in the opposite direction is referred to as exsorption. The term absorption is applied to the situation in which the insorption is greater than the exsorption. When the rate of exsorption is greater than that of insorption, the term secretion is used.

\section{Calculation}

The rate of net transport of a substance over the $25 \mathrm{~cm}$ segment studied was calculated from the perfusion flow rate and changes in the concentration of PEG, according to the formula:

$$
\begin{aligned}
& \delta \mathrm{H}_{2} \mathrm{O}=\mathrm{Vx}\left(1-\frac{\text { PEG } \mathrm{p}}{\mathrm{PEG} \mathrm{d}}\right) \\
& \delta \mathrm{S}=\mathrm{Vx}\left(\mathrm{Sp}-\mathrm{Sd} \frac{\text { PEG } \mathrm{p}}{\mathrm{PEGd}}\right)
\end{aligned}
$$

where $\delta \mathrm{H}_{2} \mathrm{O}=$ net flow of $\mathrm{H}_{2} \mathrm{O}(\mathrm{ml} / \mathrm{mn} / 25 \mathrm{~cm})$; $\delta S=$ net flow of solute $(\mathrm{ml} / \mathrm{mn} / 25 \mathrm{~cm}) ; \mathrm{V}=$ perfusion flow rate $(\mathrm{ml} / \mathrm{mn}) ;$ PEG $p=P E G$ concentration in the test solution (g/l); PEG $d=$ PEG concentration in the sample $(\mathrm{g} / \mathrm{l}) ; \mathrm{Sp}=$ solute concentration in the test solution $(\mathrm{mmol} / \mathrm{ml})$; and $S d=$ solute concentration in the sample $(\mathrm{mmol} / \mathrm{l})$.

A negative value for net movement indicated that absorption had occurred, whereas a positive value indicated secretion.

The rates of insorption of $\mathrm{Na}$ and $\mathrm{K}$ were calculated from the disappearance rate of the appropriate isotope from the intestine using the formula described by Visscher $e t a l .{ }^{16}$ The rate of exsorption was then derived by substitution in the equation:

Rate of net movement=insorption-exsorption .

\section{Analysis}

$\mathrm{Na}, \mathrm{K}, \mathrm{Cl}$, bicarbonate, and glucose were determined for each sample. PEG 4000 was measured by Hyden's turbidimetric method. ${ }^{17}$ The activities of $\mathrm{Na}^{22}$ and $\mathrm{K}^{12}$ were determined with a $\gamma$ counter (Beckmann). Other blood and urinary samples were taken for assay. Serum $\mathrm{Na}, \mathrm{K}, \mathrm{Cl}$, urea, alkaline reserve, osmolarity, and oncotic pressure were determined. In addition, aldosterone and renin activity were measured. Samples were taken upon waking in the morning and before rising on the three days before the 
TABLE III Results of jejunal perfusion with the solution I containing glucose (30 mmolll), in the six control patients and the eight cirrhotic patients

\begin{tabular}{|c|c|c|c|c|c|c|c|c|}
\hline Patient no & $\begin{array}{l}\mathrm{Net} \mathrm{flow} \\
\mathrm{H}_{2} \mathrm{O} \\
(\mathrm{ml} / \mathrm{min} / 25 \mathrm{~cm})\end{array}$ & $\begin{array}{l}\text { Net flow } \\
N a \\
(\mu \mathrm{mol} / \mathrm{min} / 25 \mathrm{~cm})\end{array}$ & $\begin{array}{l}\text { Net flow } \\
K \\
(\text { (umol/min } / 25 \mathrm{~cm})\end{array}$ & $\begin{array}{l}\text { Net flow } \\
\mathrm{Cl} \\
(\mu \mathrm{mol} / \mathrm{min} / 25 \mathrm{~cm})\end{array}$ & $\begin{array}{l}\text { Insorption } \\
\mathrm{Na} \\
(\mu \mathrm{mol} / \mathrm{min} / 25 \mathrm{~cm})\end{array}$ & $\begin{array}{l}\text { Exsorption } \\
\mathrm{Na} \\
(\mu \mathrm{mol} / \mathrm{min} / 25 \mathrm{~cm})\end{array}$ & $\begin{array}{l}\text { Insorption } \\
K \\
(\mu \mathrm{mol} / \mathrm{min} / 25 \mathrm{~cm})\end{array}$ & $\begin{array}{l}\text { Exsorption } \\
K \\
(\mu \mathrm{mol} / \mathrm{min} / 25 \mathrm{~cm})\end{array}$ \\
\hline $\begin{array}{l}1 \\
2 \\
3 \\
4 \\
5 \\
6 \\
7 \\
8 \\
\text { Patients, mean (SD) } \\
\text { Controls, mean (SD) } \\
\text { p }\end{array}$ & $\begin{array}{l}-1.79 \\
-1.65 \\
-1.16 \\
-2.2 \\
-0.3 \\
-2.1 \\
-0.6 \\
-3.1 \\
-1.61(0.9) \\
-177(0.9) \\
\text { NS }\end{array}$ & $\begin{array}{l}-200 \\
-167 \\
-137 \\
-272 \\
-483 \\
-249 \\
-120 \\
-447 \\
-259(137) \\
-244(131) \\
\text { NS }\end{array}$ & $\begin{array}{l}-3 \cdot 02 \\
-0 \cdot 3 \\
-9 \cdot 2 \\
-1 \\
-14 \cdot 3 \\
-2 \cdot 7 \\
-13 \cdot 5 \\
-15 \cdot 6 \\
-7(6 \cdot 4) \\
-6 \cdot 2(6 \cdot 1) \\
\text { NS }\end{array}$ & $\begin{array}{l}-261 \\
-191 \\
-146 \\
-268 \\
-174 \\
-288 \\
-146 \\
-452 \\
-240(102) \\
-244(133) \\
\text { NS }\end{array}$ & $\begin{array}{l}1075 \\
1063 \\
924 \\
1425 \\
972 \\
1020 \\
972 \\
1100 \\
1069(156) \\
1001(187) \\
\text { NS }\end{array}$ & $\begin{array}{l}874 \\
896 \\
787 \\
1153 \\
489 \\
771 \\
852 \\
653 \\
809(193) \\
757(157) \\
\text { NS }\end{array}$ & $\begin{array}{l}33 \\
42 \\
51 \\
56 \\
15 \cdot 2 \\
28 \cdot 6 \\
20 \cdot 8 \\
38 \\
35 \cdot 5(14) \\
31 \cdot 7(11 \cdot 8) \\
\text { NS }\end{array}$ & $\begin{array}{l}30 \\
42 \\
42 \\
55 \\
1 \\
26 \\
7 \\
22 \\
28 \cdot 1(18) \\
25 \cdot 5(11) \\
\text { NS }\end{array}$ \\
\hline
\end{tabular}

intestinal perfusion. $\mathrm{Na}, \mathrm{K}, \mathrm{Cl}$, and osmolarity were determined in urine.

\section{Statistical analysis}

Non-parametrical two tailed Mann-Whitney and Wilcoxon's rank sum tests were used. Correlation was evaluated using the two tailed Pearson's correlation coefficient. Results are expressed as mean (SD).

\section{Results}

The clinical and laboratory data for the eight cirrhotic patients studied are given in Tables I and II. No patient had diarrhoea, and faecal weight was 80 to $256 \mathrm{~g}$ per day (mean of measurements over three days).

\section{PORTAL HYPERTENSION}

The results are reported in Table II. In all cases, portal pressure estimated from the suprahepatic wedge pressure was over $21 \mathrm{mmHg}$ and was above $30 \mathrm{mmHg}(\mathrm{m}=34.6(8.4) \mathrm{mmHg}$ in six of eight patients. The portocaval gradient, estimated by the suprahepatic wedge/inferior vena cava gradient, was always above $17 \mathrm{mmHg}$ (mean 28 (6) $\mathrm{mmHg}$; normal $<8 \mathrm{mmHg}$ ) and greater than $27 \mathrm{mmHg}$ in six of eight patients.

There was little variation in plasma aldosterone concentrations and the results given in Table I are the means of the values measured in each patient. These values were greater than twice the normal in six of eight patients. Plasma renin activity was also raised and correlated with aldosterone concentrations $(r=0.86, p<0.05)$. Furthermore, the plasma aldosterone concentration correlated positively with the suprahepatic wedge pressure $(r=0.8 ; p<0.05)$.

\section{Intestinal perfusion}

The results of SI perfusions in the eight cirrhotic patients and the six control subjects are given in Table III. In both groups there was a net absorption of water $(-1 \cdot 77(0.92) \mathrm{ml} / \mathrm{min} / 25 \mathrm{~cm})$, $\mathrm{Na}(-243(131) \mu \mathrm{mol} / \mathrm{mn} / 25 / \mathrm{cm}), \mathrm{K}(-6(6)$ $\mu \mathrm{mol} / \mathrm{min} / 25 \mathrm{~cm})$, and $\mathrm{Cl}(-244(133) \mu \mathrm{mol} /$ $\mathrm{min} / 25 \mathrm{~cm}$ ) in the presence of glucose. The net flow of water, $\mathrm{Na}, \mathrm{K}$, and $\mathrm{Cl}$ did not differ significantly between the cirrhotic patients and the control subjects, nor did insorption and secretion rates of $\mathrm{Na}$ and $\mathrm{K}$.

The results of the SII perfusions are detailed in Table IV. The net flows in control subjects were slight, with secretion of $\mathrm{H}_{2} \mathrm{O}(+0.03(0.7)$ $\mathrm{ml} / \mathrm{min} / 25 \mathrm{~cm})$ and absorption of $\mathrm{Na}(-69(12)$ $\mu \mathrm{mol} / \mathrm{min} / 25 \mathrm{~cm}), \mathrm{K}(-5.6(4 \cdot 2) \mu \mathrm{mol} / \mathrm{min} /$ $25 \mathrm{~cm})$, and $\mathrm{Cl}(-76.9(61) \mu \mathrm{mol} / \mathrm{min} / 25 \mathrm{~cm})$. In cirrhotic patients net flows were also small, values were $\mathrm{H}_{2} \mathrm{O}-0.07(0.2) \mathrm{ml} / \mathrm{min} / 25 \mathrm{~cm}$, $\mathrm{Na}-32.5(27) \mu \mathrm{mol} / \mathrm{min} / 25 \mathrm{~cm}, \mathrm{~K}(-3.4$ (3.9) $\mu \mathrm{mol} / \mathrm{min} / 25 \mathrm{~cm}$, and $\mathrm{Cl}-52.85(35) \mu \mathrm{mol} / \mathrm{min} /$ $25 \mathrm{~cm}$. Absorption of $\mathrm{Na}$ was lower in the cirrhotic group than in the control group $(p<0.01)$, because of a higher exsorption (Table IV). Net flows were similar for $\mathrm{H}_{2} \mathrm{O}, \mathrm{Cl}$, and $\mathrm{K}(\mathrm{p}>0 \cdot 1)$. Insorption and exsorption of $\mathrm{K}$ did not differ between cirrhotic patients and control subjects. Finally, there was no correlation between movement of water or electrolytes and suprahepatic wedge pressure.

Comparison of results obtained with SI and SII showed that SI had strongly stimulated the absorption of $\mathrm{H}_{2} \mathrm{O}$ (Fig 1), $\mathrm{Na}$ (Fig 2), and $\mathrm{Cl}$ compared with SII $(p<0.01)$ in both cirrhotic patients and control subjects.

The results of perfusion of SI, 75 minutes after iv injection of $400 \mathrm{mg}$ spironolactone, are given in Table V. In cirrhotic patients the net flows of $\mathrm{H}_{2} \mathrm{O}(-0.97(0.67) \mathrm{ml} / \mathrm{min} / 25 \mathrm{~cm}), \mathrm{Na}(-119.6$

TABLE IV Results of jejunal perfusion with the solution II containing mannitol ( 30 mmol/l), in the six control patients and the eight cirrhotic patients

\begin{tabular}{|c|c|c|c|c|c|c|c|c|}
\hline Patient no & $\begin{array}{l}\text { Net flow } \\
\mathrm{H}_{2} \mathrm{O} \\
(\mathrm{ml} / \mathrm{min} / 25 \mathrm{~cm})\end{array}$ & $\begin{array}{l}\text { Net flow } \\
\mathrm{Na} \\
(\mu \mathrm{mol} / \mathrm{min} / 25 \mathrm{~cm})\end{array}$ & $\begin{array}{l}\text { Net flow } \\
K \\
(\mu \mathrm{mol} / \mathrm{min} / 25 \mathrm{~cm})\end{array}$ & $\begin{array}{l}\text { Net flow } \\
C l \\
(\mu \mathrm{mol} / \mathrm{min} / 25 \mathrm{~cm})\end{array}$ & $\begin{array}{l}\text { Insorption } \\
\mathrm{Na} \\
(\mu \mathrm{mol} / \mathrm{min} / 25 \mathrm{~cm})\end{array}$ & $\begin{array}{l}\text { Exsorption } \\
\mathrm{Na} \\
(\mu \mathrm{mol} / \mathrm{min} / 25 \mathrm{~cm})\end{array}$ & $\begin{array}{l}\text { Insorption } \\
K \\
(\mu \mathrm{mol} / \mathrm{min} / 25 \mathrm{~cm})\end{array}$ & $\begin{array}{l}\text { Exsorption } \\
K \\
(\mu \mathrm{mol} / \mathrm{min} / 25 \mathrm{~cm})\end{array}$ \\
\hline $\begin{array}{l}1 \\
2 \\
3 \\
4 \\
5 \\
6 \\
7 \\
8 \\
\text { Patients, mean (SD) } \\
\text { Controls, mean (SD) } \\
\text { p }\end{array}$ & $\begin{array}{l}-0.12 \\
+0.29 \\
+0.25 \\
-0.29 \\
+0.2 \\
-0.67 \\
-0.3 \\
+0.1 \\
+0.05(0.34) \\
+0.03(0.75) \\
\text { NS }\end{array}$ & $\begin{array}{l}-6 \cdot 57 \\
-0 \cdot 6 \\
-60 \cdot 15 \\
-57 \\
-38 \cdot 7 \\
-58 \\
-38 \cdot 1 \\
-6 \cdot 8 \\
-33 \cdot 2(25) \\
-69 \cdot 8(12 \cdot 4) \\
<0 \cdot 01\end{array}$ & $\begin{array}{l}-6 \cdot 7 \\
-5 \cdot 2 \\
+3 \cdot 2 \\
-5 \cdot 1 \\
-2 \cdot 4 \\
0 \\
-2 \cdot 5 \\
-9 \cdot 1 \\
-3 \cdot 4(3 \cdot 9) \\
-5 \cdot 6(4 \cdot 2) \\
\text { NS }\end{array}$ & $\begin{array}{l}-16 \\
-1 \\
-65 \\
-75 \\
-100 \\
-71 \\
-75 \\
-20 \\
-52 \cdot 8(35) \\
-76 \cdot 9(61) \\
\text { NS }\end{array}$ & $\begin{array}{l}829 \\
779 \\
720 \\
629 \\
577 \\
732 \\
653 \\
821 \\
717(91) \\
656(35) \\
\text { NS }\end{array}$ & $\begin{array}{l}836 \\
779 \\
780 \\
686 \\
616 \\
790 \\
692 \\
828 \\
751(77) \\
586(32) \\
<0.05\end{array}$ & $\begin{array}{l}21 \\
40 \\
41 \\
35 \\
10 \\
18 \\
17 \\
28 \\
26 \cdot 2(11 \cdot 6) \\
22 \cdot 7(12 \cdot 7) \\
\text { NS }\end{array}$ & $\begin{array}{l}14.8 \\
34 \cdot 7 \\
38 \cdot 1 \\
29 \cdot 9 \\
7 \cdot 3 \\
17 \cdot 7 \\
14 \cdot 9 \\
18.7 \\
22(10 \cdot 8) \\
17(11 \cdot 9) \\
\text { NS }\end{array}$ \\
\hline
\end{tabular}




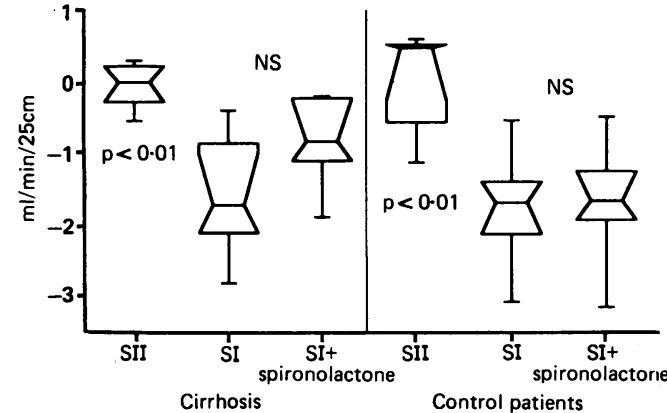

Figure 1: Box-whiskers plots of median net flows of $\mathrm{H}_{2} \mathrm{O}$ in cirrhotic and control patients, during intestinal perfusion carried out with SI (glucose 30 mmolll), SII (mannitol $30 \mathrm{mmol} / \mathrm{l})$ and $S I, 75$ minutes after an injection of spironolactone. In these plots the top of the box represents the third quartile and the bottom the first one. The median is shown as a solid horizontal line within the box. Whiskers above and below the box stretch to the furthest value within the first nine deciles.

$(74 \cdot 4) \mu \mathrm{mol} / \mathrm{min} / 25 \mathrm{~cm})$, and $\mathrm{Cl}(-126 \cdot 5(83 \cdot 8)$ $\mu \mathrm{mol} / \mathrm{min} / 25 \mathrm{~cm}$ ) were lower than in the control group $-\mathrm{H}_{2} \mathrm{O}-1.58(0.85) \mathrm{ml} / \mathrm{min} / 25 \mathrm{~cm}$, $\mathrm{Na}-227 \cdot 5(129) \mu \mathrm{mol} / \mathrm{min} / 25 \mathrm{~cm}, \mathrm{Cl}-225 \cdot 3$ (130) $\mu \mathrm{mol} / \mathrm{min} / 25 \mathrm{~cm}(\mathrm{p}<0.05)$. Furthermore, in cirrhotic patients, the insorption rate of $\mathrm{Na}$ was lower $(p<0.05)$ and that of $K$ was greater $(p<0.05)$ than in control subjects (Table V). The cirrhotic patients had lower net flows of $\mathrm{Na}$ and Cl than with SI perfused alone $(\mathrm{p}<0.05)(\mathrm{Fig} 2)$. In control subjects there was no statistically significant difference between all net flows observed with SI alone and SI plus spironolactone (Fig 2).

\section{Discussion}

The purpose of this study was to show an influence of aldosterone on the flow of water and electrolytes into the jejunum of patients with progressive portal hypertension caused by cirrhosis, and therefore with hepatocellular insufficiency. We have shown a small increase in intestinal secretion of $\mathrm{Na}$ and $\mathrm{Cl}$ in cirrhotic patients compared with control subjects under the same conditions of perfusion with glucose (SII). As expected, the perfusion of a solution with glucose (SI) favoured absorption of $\mathrm{H}_{2} \mathrm{O}$, $\mathrm{Na}$, and $\mathrm{Cl}$ in control subjects as well as in cirrhotic patients. A previous injection of an aldosterone antagonist significantly lowered the absorption rates of $\mathrm{H}_{2} \mathrm{O}, \mathrm{Na}$, and $\mathrm{Cl}$. For $\mathrm{Na}$ this was because of a decrease in insorption, but we cannot speculate about unidirectional flux of water and $\mathrm{Cl}$ as they were not investigated at this

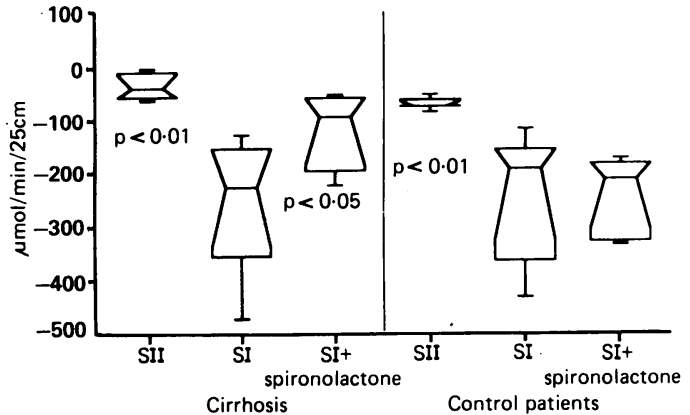

Figure 2: Box-whiskers plots of median net flows of $\mathrm{Na}$ in cirrhotic and control patients, during intestinal perfusion carried out with SI (glucose $30 \mathrm{mmol} / \mathrm{l}$ ), SII (mannitol $30 \mathrm{mmol} / \mathrm{l}$ ) and SI, 75 minutes after an injection of spironolactone. The plots are defined in Figure 1.

time. An increased exsorption of water is a possibility that cannot be ruled out.

Intestinal secretion in animals has been shown by a model of acute portal hypertension with a healthy liver..$^{6-11}$ Passive secretion developed in dogs when a threshold pressure of $20 \mathrm{mmHg}$ was reached, and it increased in proportion to portal pressure beyond a pressure of $23 \mathrm{mmHg}$. " All the cirrhotic patients we studied had a suprahepatic wedge pressure greater than this figure. In alcoholic cirrhotic patients the suprahepatic wedge pressure is considered to be identical to the portal pressure ${ }^{18}$ in the absence of any drug, particularly betablockers, ${ }^{19}$ capable of modifying the splanchnic circulation. All of our cirrhotic patients were obliged to abstain from drinking alcohol for at least 15 days before the study in order to eliminate its effects on intestinal secretion. ${ }^{20-23}$ The solution containing glucose (SI), designed to stimulate electrolyte absorption, ${ }^{2+}$ induced equal absorption of $\mathrm{H}_{2} \mathrm{O}, \mathrm{Na}, \mathrm{K}$, and $\mathrm{Cl}$, in both cirrhotic patients and control subjects. This phenomenon had already been observed in two studies using an intestinal perfusion technique. ${ }^{45}$ Perfusion of the solution without glucose (SII) brought about a smaller absorption of $\mathrm{Na}$ and $\mathrm{Cl}$ in cirrhotic patients than in control subjects. Two previous studies ${ }^{+5}$ did not clearly show this phenomenon, while Norman et $a l,{ }^{4}$ using tritiated water, showed an increase in exsorption in eight cirrhotic patients $(0.05<\mathrm{p}<0.1)$. In this study the eight cirrhotic patients, six of whom were alcoholic had relatively low suprahepatic wedge pressures (mean $=29 \mathrm{mmHg}$ ), which were less than $28 \mathrm{mmHg}$ in four. Unlike studies in animals, we found no correlation between the portal pressure and water or electrolyte secretions. Further-

TABLE V Results of jejunal perfusion with the solution I (30 mmol/l of glucose) after iv injection of spironolactone

\begin{tabular}{|c|c|c|c|c|c|c|c|c|}
\hline Patient no & $\begin{array}{l}\mathrm{Net} \mathrm{flow} \\
\mathrm{H}_{2} \mathrm{O} \\
(\mathrm{ml} / \mathrm{min} / 25 \mathrm{~cm})\end{array}$ & $\begin{array}{l}\text { Net flow } \\
\mathrm{Na} \\
(\mu \mathrm{mol} / \mathrm{min} / 25 \mathrm{~cm})\end{array}$ & $\begin{array}{l}\text { Net flow } \\
K \\
(\mu \mathrm{mol} / \mathrm{min} / 25 \mathrm{~cm})\end{array}$ & $\begin{array}{l}\text { Net flow } \\
C l \\
(\mu \mathrm{mol} / \mathrm{min} / 25 \mathrm{~cm})\end{array}$ & $\begin{array}{l}\text { Insorption } \\
\mathrm{Na} \\
(\mu \mathrm{mol} / \mathrm{min} / 25 \mathrm{~cm})\end{array}$ & $\begin{array}{l}\text { Exsorption } \\
\mathrm{Na} \\
(\mu \mathrm{mol} / \mathrm{min} / 25 \mathrm{~cm})\end{array}$ & $\begin{array}{l}\text { Insorption } \\
K \\
(\mu \mathrm{mol} / \mathrm{min} / 25 \mathrm{~cm})\end{array}$ & $\begin{array}{l}\text { Exsorption } \\
K \\
(\mu \mathrm{mol} / \mathrm{min} / 25 \mathrm{~cm})\end{array}$ \\
\hline $\begin{array}{l}1 \\
2 \\
3 \\
4 \\
5 \\
6 \\
\text { Patients, mean (SD) } \\
\text { Controls, mean (SD) } \\
\text { p }\end{array}$ & $\begin{array}{l}-1 \cdot 13 \\
-0.23 \\
-1.02 \\
-0.65 \\
-2 \\
-0.2 \\
-0.87(0.67) \\
-1.58(0.85) \\
<0.05\end{array}$ & $\begin{array}{l}-199 \\
-78 \\
-110 \cdot 9 \\
-49 \cdot 9 \\
-223 \\
-56 \cdot 7 \\
-119(74) \\
-227(129) \\
<0.05\end{array}$ & $\begin{array}{l}-0 \cdot 95 \\
+7 \cdot 6 \\
-10 \cdot 3 \\
-15 \cdot 8 \\
-2 \cdot 5 \\
-34 \cdot 6 \\
-9 \cdot 4(14 \cdot 7) \\
-7 \cdot 5(6 \cdot 3) \\
\text { NS }\end{array}$ & $\begin{array}{l}-146 \\
-3 \\
-136 \\
-128 \\
-260 \\
-86 \\
-126(84) \\
-225(130) \\
<0.05\end{array}$ & $\begin{array}{l}678 \\
890 \\
814 \\
846 \\
656 \\
704 \\
762(98) \\
945(137) \\
<0.05\end{array}$ & $\begin{array}{l}479 \\
812 \\
703 \\
796 \\
433 \\
648 \\
645(159) \\
705(134) \\
\text { NS }\end{array}$ & $\begin{array}{l}39 \\
29 \cdot 8 \\
52 \\
51 \cdot 3 \\
19 \cdot 3 \\
37 \cdot 4 \\
37 \cdot 2(11 \cdot 4) \\
24 \cdot 4(9 \cdot 5) \\
<0 \cdot 05\end{array}$ & $\begin{array}{l}38.1 \\
37 \cdot 6 \\
41 \cdot 7 \\
35 \cdot 5 \\
16 \cdot 8 \\
2 \cdot 8 \\
26 \cdot 1(14 \cdot 9) \\
17 \cdot 4(10 \cdot 5) \\
\text { NS. }\end{array}$ \\
\hline
\end{tabular}

$(-)=$ absorption; $(+)=$ secretion. p:statistical significance according to the Mann-Whitney rank sum test. 
more, the values we observed never reached those obtained in animal models. ${ }^{6911}$ These two facts suggest the existence of regulatory mechanisms in cirrhotic patients, some of which are known: (1) a low serum albumin concentration caused by hepatocellular insufficiency; (2) ascites, resulting in increased intraabdominal pressure, (3) the chronicity and progression of portal hypertension, and (4) hyperaldosteronism. We examined the latter parameter since hyperaldosteronism is common in alcoholic cirrhosis. ${ }^{25}$ All our patients had an increased plasma aldosterone value which correlated with the plasma renin activity on one hand $(r=0.86, p<0.05)$ and with the portal pressure $(r=0.8, p<0.05)$ on the other, as previously described by others. ${ }^{26}$ An inverse correlation between the plasma aldosterone value and the size of the intercellular spaces measured on jejunal biopsy specimens was shown by Norman et al. ${ }^{4}$ This fact suggests that hyperaldosteronism could play a regulatory role in the hydroionic movements in the jejunum of cirrhotic patients. This dilatation of intercellular spaces linked to portal hypertension has already been shown in animal models by suddenly increasing the portal vein flow using high volume saline perfusions. ${ }^{3}$ We examined the role of aldosterone by injecting $400 \mathrm{mg}$ of its antagonist, spironolactone, iv, and waiting 75 minutes before the next perfusion of SI. Aldosterone in man increases the absorption of $\mathrm{Na}$ in the colon ${ }^{27}$ and also acts directly on both $\mathrm{Na}$ and $\mathrm{K}$ transfer in the canine ileum. ${ }^{28-30}$ Spironolactone inhibits this action, ${ }^{12}$ but there is no physiological or pharmacological evidence that it affects directly the transport of $\mathrm{Na}$ and $\mathrm{K}$ in the jejunum. Furthermore, in control subjects, we observed no difference between the net flows with SI alone and $\mathrm{SI}+$ spironolactone. Alternatively, in the cirrhotic patients, spironolactone decreased the net flows of $\mathrm{Na}$ and $\mathrm{Cl}$ significantly compared with control subjects and compared with SI alone, as a consequence of a lower insorption of $\mathrm{Na}$. The observed variations correlated with neither suprahepatic wedge pressure nor the plasma aldosterone value.

One could therefore suggest that aldosterone, which has specific jejunal receptors, ${ }^{31}$ and whose concentration is increased in cirrhosis, could mask a passive intestinal secretion caused by portal hypertension. This may constitute one of the adaptative mechanisms of the digestive tract, thereby preventing intestinal secretion, as opposed to what is observed with acute portal hypertension in animal models. On the basis of this hypothesis, the consequences of a sudden increase in portal pressure, or of saline overload, should be explored in man. The respective roles of the decrease in oncotic pressure caused by hepatocellular insufficiency and the increase in abdominal pressure because of ascites remain to be examined.

1 McCormack TT, Sims J, Eyre-Brook I, Kennedy H, Goepel J, Johnson AG, Triger DR. Gastric lesions in portal hyper- tension: inflammatory gastritis or congestive gastropathy. Gut 1987; 26: 1226-32.

2 Papazian A, Braillon A, Dupas JL, Sevenet F, Capron JP. Portal hypertensive gastric mucosa: an endoscopic study. Gut 1986; 27 : 1199-203.

3 Dibona DR, Chen LC, Shard GW. A study of intercellula spaces in the rabbit jejunum during acute volume expansion and after treatment with cholera toxin. $\mathcal{F}$ Clin Invest 1974; 53: $1300-7$.

4 Norman DA, Atkins JM, Seelig LC, Gomez-Sanchez C, Kress GJ. Water and electrolyte movement and mucosal morphology in the jejunum of patients with portal hypermorphology in the jejunum of patients with

5 Talley RB, Schedl HP, Clifton JA. Small intestinal glucose electrolyte, and water absorption in cirrhosis. Gastroenterology $1964 ; 47: 382-7$.

6 Hakim AA, Lifson N. Effects of pressure on water and solute transport by dog intestinal mucosa in vitro. Am $\mathcal{F}$ Physio $1969 ; 216(2)$ : $276-84$.

7 Johnson PC, Richardsons DR. The influence of venous pressure on filtration forces in the intestine. Microvascular Res 1974; 7: 296-306.

8 Lee JS. Effects of pressures on water absorption and secretion in rat jejunum. Am $\mathcal{F}$ Physiol 1973; 224: 1338-44.

9 Shields R, Code CF. Effect of increased portal pressure on sorption of water and sodium from the ileum of dog. sorption of water and sodium fror

10 Winne D. Der einfluss der durchblutung auf die wasser und salz resorption in jejunum der rate. Arch Expl Patho Pharmakol 1970; 265: 425-41.

11 Yablonski ME, Lifson N. Mechanism of production of intestinal secretion by elevated venous pressure. $\mathcal{F} \mathrm{Cl}$ Invest 1976; 57: 904-15.

12 Elmslie RG, Mulholland AT, Shields R. Blocking by spironolactone (SC0420) of the action of aldosterone infusions upon the intestinal absorption of potassium, sodium and water. Gut 1966; 7: 697-9.

13 Fordtran JS. Marker perfusion technics for measuring intestinal absorption in man. Gastroenterology 1966; 51: 1089-93.

14 Modigliani R, Rambaud JC, Bernier JJ. The method of intestinal perfusion of the human small intestine I. Principle and technique. Digestion 1973; 9: 176-92.

15 Sladen GE, Dawson AM. Further studies on the perfusion method for measuring intestinal absorption in man: the effect of a proximal occluding balloon and a mixing segment. Gut 1970: 11: 947-54.

16 Visscher MB, Fechter ES, Carr CW, Gregor HP, Bushey MS, Barker DE. Isotopic tracer studies on the movement of water and ions between intestinal lumen and blood. Am F Physiol 1944; 142: $550-75$.

17 Malawer SJ, Powel DW. An improved turbidimetric analysis of polyethylene glycol utilizing on emulsifier. Gastroof polyethylene glycol util

18 Viallet A, Joly JG, Marleau D, Lavoie P. Comparison of free portal venous pressure and wedged hepatic venous pressure in patients with cirrhosis of the liver. Gastroenterology 1970 59: 372-5.

19 Valla D, Bercoff E, Menu Y, Bataille C, Lebrec D. Discrepancy between wedged hepatic venous pressure and portal venous pressure after acute propranolol administration in patients with alcoholic cirrhosis. Gastroenterology 1984; 86: 1400-3.

20 Dinda PK, Beck IT, Beck $M$ et al. Effect of ethanol and sodium dependant glucose transport in the small intestine of sodium dependant glucose transport in the small in

21 the hamster. Gastroenterology 1975; 68: 1517-26. adenylcyclase by ethanol. $f$ Lab Clin Med 1971; 78: 336-42.

22 Krasner N, Cochran KM, Russel RI, Carmichael HA Thompson GG. Alcohol and absorption from the smal intestine. 1-Impairment of absorption from the small intestine in alcoholics. Gut 1976; 17: 245-8.

23 Mekhjian HS, May ES. Acute and chronic effects of ethanol on fluid transport in the human small intestine. Gastroenterology 1977; 72: 1280-6.

24 Fordtran JS. Stimulation of active or passive sodium absorption by sugars in the human jejunum. $\mathcal{F}$ Clin Invest 1975; 55 728 .

25 Wilkinson SP, Williams R. Progress report: renin-angiotensin-aldosterone in cirrhosis. Gut 1980; 21 : 545-54.

26 Bosch J, Arroyo V, Betriu A, Mas A, Carrino F, Rivera F, Navarro-Lopez F, Rodes J. Hepatic hemodynamics and the renin-angiotensin-aldosterone system in cirrhosis. Gastroenterology 1980; 78: 92-9.

27 Levitan R, Ingelfinger FJ. Effect of d-aldosterone on salt and water absorption from the intact human colon. $\mathcal{F}$ Clin Invest $1965 ; 44: 801$

28 Charney AN, Kinsey MD, Myers L, Giannella RA, Gots RE $\mathrm{Na}+, \mathrm{K}+$ activated adenosine triphosphatase and intestinal electrolyte transport. Effect of adrenal steroids. $\mathcal{f}$ Clin Invest 1975; 56: 653-60.

29 Berger EY, Kanzaki G, Steele JM. The effect of deoxycorticosterone on the unidirectional transfers of sodium and potassium into and out of the dog intestine. F Physiol (Lond) $1960 ; 151: 352-62$.

30 Shields R, Mulholland AT, Elmslie RG. Action of aldosterone upon the intestinal transport of potassium, sodium and water. Gut 1966; 7: 686-96.

31 Pressley L, Funder JW. Glucocorticoid and mineralocorticoid receptors in gut mucosa. Endocrinology 1975; 97: 588-96. 